Journal of Horticulture and Forestry Vol. 4(11), pp. 178-180, November 2012

Available online at http://www.academicjournals.org/JHF

DOI: $10.5897 / J H F 12.025$

ISSN 2006-9782 @2012 Academic Journals

\title{
Review
}

\section{Genus: Strelitzia}

\section{Marcos Ribeiro da Silva Vieira ${ }^{\star}$ Giuseppina Pace Pereira Lima², Damiana Cleuma de Medeiros ${ }^{4}$, Ângela Vacaro de Souza ${ }^{1}$ and Emídio Cantidio Almeida de Oliveira ${ }^{3}$}

\footnotetext{
${ }^{1}$ Department of Plant Production (Horticulture), Universidade Estadual Paulista, CEP: 18601-060, Botucatu, SP, Brazil.

${ }^{2}$ Department of Chemistry and Biochemistry, Institute of Biosciences, Paulista State University, Botucatu, SP, Brazil.

${ }^{3}$ Universidade Federal Rural de Pernambuco, Unidade Acadêmica de Serra Talhada, CEP: 59909-460, Serra Talhada, PE, Brasil.

${ }^{4}$ Universidade Federal do Rio Grande do Norte (UFRN), Macaíba, RN, Brazil.
}

Accepted 20 September, 2012

\begin{abstract}
This review aimed to show the importance of Strelitzia in Floriculture. The genus named after the duchy of Mecklenburg-Strelitz, birthplace of Queen Charlotte of United Kingdom. A commom name of the genus is bird of paradise flower, because of a supposed resemblance of its flowers to the bird of paradise. In this context, it is currently a growing interest in exotic cultures, with tropical characteristics, such as species of the family Strelitziaceae. Thus, it was observed that the production of agricultural activity, Strelitzia is one of increasing social and economic importance in the world.
\end{abstract}

Key words: Zingiberales, Strelitziaceae, cut flower, inflorescence.

\section{INTRODUCTION}

Tropical Floriculture is an activity that is on the rise in Brazil and the world stand by agribusiness as generator of income and suitable as an alternative crop for small farmers (Lins and Coelho, 2004). The main species of tropical flowers belong to the order Zingeberales, which naturally exploited or occur in conventional plantations in the tropical zone of America, West Asia and the Pacific. The Zingeberales are herbaceous, rhizomatous, perennial arborescent or reduced sizes, characterized by their bract color and shapes, greater durability after harvest, of great beauty, and used for ornamental environments (Assis et al., 2002; Lins and Coelho, 2004).

\section{ASPECTS OF TAXONOMY: HISTORY AND CLASSIFICATION Of STRELITZIA}

The order Zingeberales is known within the monocots. It is essentially tropical and subtropical in their distribution, being in some regions of the world. Additionally, the order

\footnotetext{
${ }^{*}$ Corresponding author. E-mail: m.r.s.v@hotmail.com.
}

brings together 8 families, 89 genera and about 1800 species (Berry and Kress, 1991). The families Zingiberaceae, Marantaceae, Helicon-iaceae, Lowiaceae, Costaceae and Strelitziaceae are recognized for their ornamental potential. Cronquist (1981) established five families within the order and they are Zingiberaceae, Costaceae, Marantaceae, Heliconiaceae, and Strelitziaceae. Phylogenetically, this order is subject to discussion, as Dahlgren et al. (1985), classified it into eight families; Zingiberaceae, Musaceae, Heliconiaceae, Costaceae, Cannaceae, Marantaceae, Lowiaceae and Strelitziaceae.

The family Strelitziaceae has two genera and the genus that stands out is the Strelitzia. They include numerous species, among them, Strelitzia reginae Banks ex Aiton (Figure 1), Strelitzia alba (Figure 2), white flowers, the Strelitzia caudata (Figure 3), with bluish flowers and Strelitzia juncea (Figure 4), all originating from South Africa and introduced in Europe in 1770, from where it spread throughout the world (Van Jaarsveld, 2008; Winter and Jaba, 2011).

The species is the most widely cultivated Strelitzia ( $S$. reginae Banks ex Aiton), also known as queen of paradise, the flower-queen, bird of paradise and 


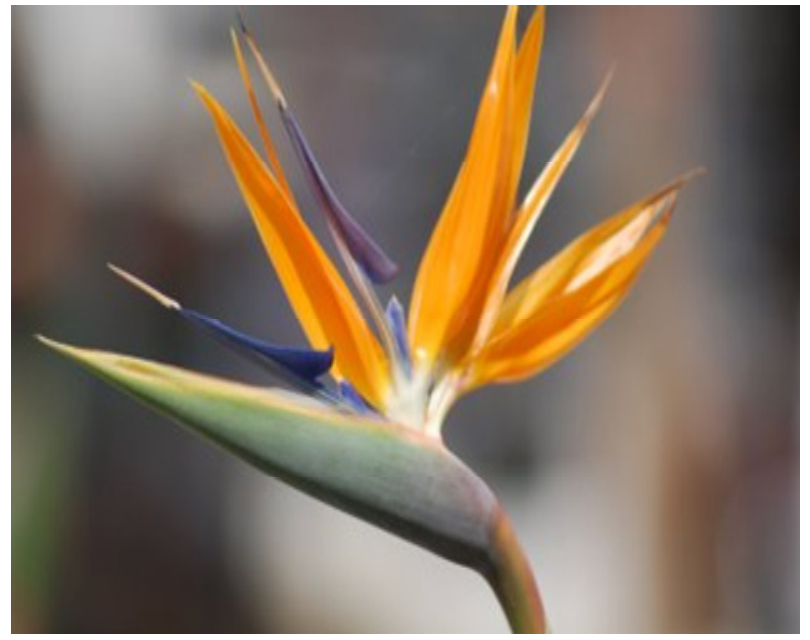

Figure 1. Strelitzia reginae.

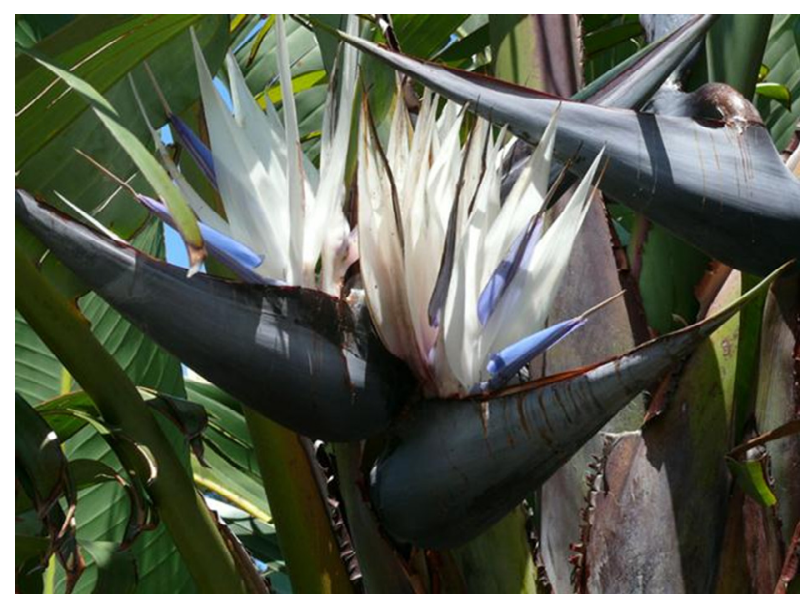

Figure 2. Strelitzia alba.

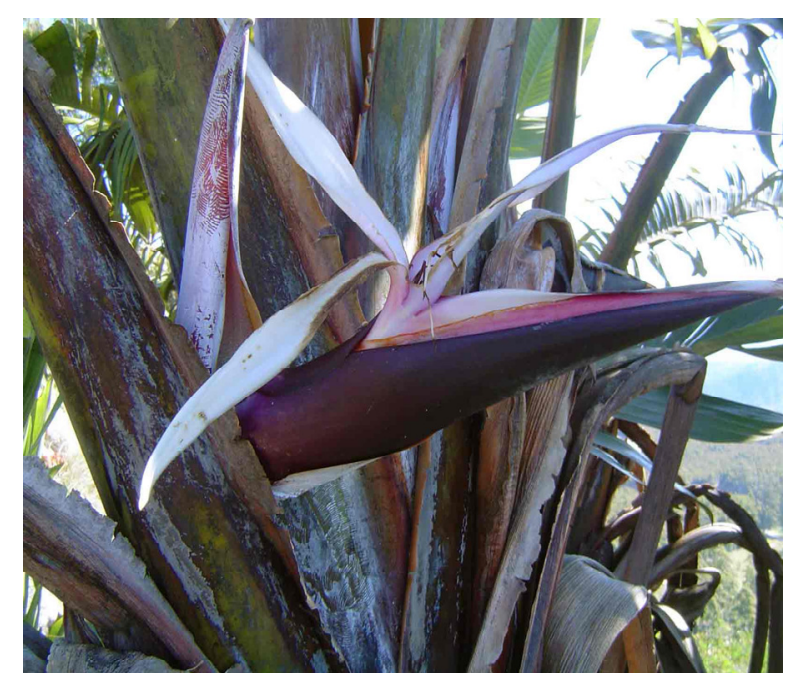

Figure 3. Strelitzia caudata.

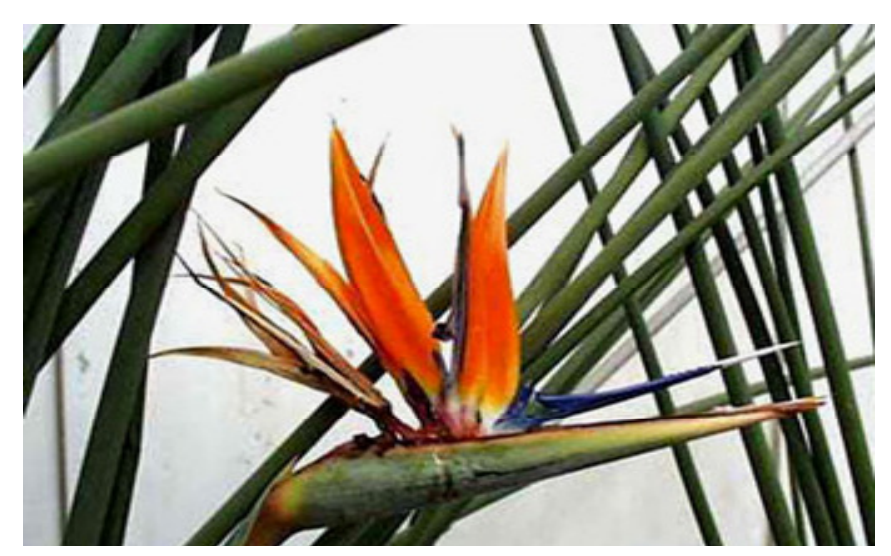

Figure 4. Strelitzia juncea.

bananeirinha-of-garden (Karsten, 2009). It has been cultivated for the production of cut flowers, mainly by post-harvest durability, size, long stem and bright colors of their flowers (Pivetta et al., 2007). In Brazil, the cultivation of tropical plants is still new, existing, according to the latest survey by Ibraflor (2002), an area of 65.4 with flowers for cutting Strelitzia.

The Strelitzia is a herbaceous plant Rhizome with firm and coriaceous leaves (Lorenzi and Souza, 2001). The flowers open in succession within bract Amarelle-green sepals. Three of these flowers have large orange and two blue petals modified arrow-shaped, which are the sex organs (Castro, 1995; Lorenzi and Souza, 2001).

Propagation is by seed or by clump division (Bautitz and Carvalho, 2007; Pivetta et al., 2007). Propagation by seeds has a large number of fruits for inflorescence and can be 1 to 6 and the number of seeds produced in each fruit, an average of 30 . The pollen is released before the stigma becomes receptive (protrandria), favoring crosspollination and a satisfactory production of seeds (Pivetta et al., 2007).

The Strelitzia is a plant that produces flowers throughout the year, especially during summer. They have good production in warm climates and optimum temperatures of close to $25^{\circ} \mathrm{C}$, while the minimum temperature for better production is $10^{\circ} \mathrm{C}$ and relative humidity of 70\% (Brickell et al., 1996; Lamas, 2002).

According to the newspaper PlantzAfrica, normally start flowering when the pot gets a bit crowded or when the clump is starting to become denser. Starting from autumn until the beginning of spring water should be reduced. If planted in the garden, mix the soil surrounding the plant so that it is high in drainage - coarse sand and grit is added. Also, provide granular slow release fertilizer in the mix. At the end of winter surround the clumps with composted leafmould or aged manure. Strelitzia in full soil rarely requires additional watering: one or two buckets of water twice a month should be enough - wait until the soil has been dried for a few days before it is watered. 
The classification of flowers is made by observations of color, occurrence of injuries, presence of pests and diseases, and length of the spathe (bract) (Lamas, 2002). In Strelitzia the biggest problem in post-harvest is incomplete opening on the inflorescences few days before harvest (Pizano, 2005; Hassan, 2009). These effects observed can be attributed to attack by pathogens, as described in sames researched.

According to different authors (Pitta, 1990; Sewake and Uchida, 1995), the Botrytis fungus is responsible for disease in protected cultivation of flowers, and it has caused serious losses in tropical and subtropical flowers planted, as Strelitzia. Initial symptoms appear as small bright spots on the petals, sepals and bracts, which evolve into a dark colored stain (Pitta, 1990; Sewake and Uchida, 1995), preventing the marketing of the product. According to these authors, when symptoms are observed in the field, you can make a prior selection to discard infected inflorescences. However, in most cases, the symptoms are not apparent at the time of packing, remaining quiescent during storage and transport, and manifesting when environmental conditions become favorable especially with increasing humidity.

\section{CONCLUSION}

We concluded that tropical flowers like Strelitzia have gained prominence and becoming an alternative and the most growing plant in the agricultural sector.

\section{REFERENCES}

Assis SMP, Marinho RRL, Goim Júnior, MGC, Menezes M, Rosa RCT (2002). Doenças e pragas de helicônias. Diseases and pests of helicônias. Recife: UFRPE. p. 102.

Bautitz F, Carvalho RIN (2007). Propagação vegetativa de estrelítzia com diversos tipos de mudas e substratos. Revista Acadêmica: Ciências Agrárias e Ambientais 5(1):47-55.

Berry F, Kress WJ (1991). Heliconia: an identification guide. Washington and London: Smithsoniam Institution Press. p. 334.

Brickell C, Zuk J, Zuk JD (1996). American Horticultural Society A-Z Encyclopedia of Garden Plants. Am. Hortic. Soc. 1:576.

Castro CEF (1995). Inter-relações das famílias das zingiberales. Revista Brasileira de Horticultura Ornamental. 1:2-11.

Cronquist AN (1981). An integrated system of classication of flowering plants. Columbia university Press, New York.
Dahlgre RMT, Clifford HT, Yeo PF (1985). The families of the monocotyledons: structure, evolution and taxonomy. Springer-Verlag, Sn.

Hassan FAS (2009). Influence of 8-Hydroxyquinoline sulphate and sucrose treatments on the post-harvest quality of cut flowers of Strelitzia reginae and Hippeastrum vittatum. Acta Agronomica Hungarica 57:165-174.

Ibraflor (2002). Relatório do Diagnóstico da Produção de Flores e Plantas Ornamentais. Brasileira [CD - Rom]. Campinas: s.n.

Karsten J (2009). Envolvimento da peroxidase e polifenoloxidases no bloqueio xilemático de hastes de ave-do-paraiso (Strelitzia reginae). Dissertação apresentada a Universidade Federal de Viçosa (Mestrado em Fisiologia Vegetal), Viçosa, Minas Gerais.

Lamas AM (2002). Floricultura tropical: técnicas de cultivo. Recife: SEBRAE-PE. p. 87.

Lins SRO, Coelho RSB (2004). Ocorrência de doenças em plantas ornamentais tropicais no Estado de Pernambuco. Fitopatologia Brasileira 29:332-335.

Lorenzi H, Souza HM (2001). Plantas ornamentais no Brasil: arbustivas, herbáceas e trepadeiras. Nova Odessa: Plantarum. p. 1088.

Pitta GPB (1990). Flores e plantas ornamentais para exportação: aspectos fitossanitários. Brasília, DF: Embrapa - SPI, p.50.

Pivetta KFL, Barbosa JG, Araújo EF (2007). Propagação de palmeiras e strelitzia. In: Barbosa J G, Lopes LC. Propagação de Plantas Ornamentais. pp. 43-70.

Pizano M (2005). International market trends-tropical flowers. Acta Horticulturae 683:79-86.

Sewake KT, Uchida JY (1995). Diseases of heliconia in Hawaii. Honolulu: Institute of Tropical Agriculture and Human Resources. p. 18.

Van Jaarsveld E (2008). Strelitzia reginae Banks ex Aiton. Subsp. Mzimvubuensis Van Jaarsv. (from the SANBI's PlantzAfrika web-site) http://www.plantzafrica.com/plantqrs/strelitzregmzimvu.htdm.

Winter jP, Xaba (2011). Strelitziajuncea Link. (from the SANBI's PlantzAfrika http://www.plantzafrica.com/plantgrs/strelitzjun.htm. web-site) 